\title{
The effects of a cholinesterase Inhibitor on place learning in mice
}

\section{H. KENT MERRILL, Brigham Young University, Provo, Utah 84601}

Albino mice were trained on a three-table test for place learning. Prior to each of 15 daily training trials a control group was injected i.p. with saline, and five drug groups were injected i.p. with either $.05, .075, .10, .125$, or $.15 \mu \mathrm{g}$ of eserine per gram of body weight. When the drug groups were compared with the control group, the lowest $(.05 \mu \mathrm{g})$ and highest $(.15 \mu \mathrm{g})$ drug dosages significantly impaired learning, while the intermediate dosages had no effect on learning. There were no differences among the groups in terms of motor performance as reflected by running time scores. The results do not support a hypothesis that there is a positive correlation between acetylcholine activity and learning ability on the task used.

Several investigators (Carlton, 1963; Deutsch \& Deutsch, 1966; Reeves, 1967; Rosenzweig, Krech, \& Bennett, 1960) have pointed out the importance of cholinergic mechanisms for leamed behavior.

Carlton (1963) and Reeves (1967) reviewed the behavioral effects of pharmacological manipulations of cholinergic neural transmission, and both came to the conclusion that, although the exact role of $\mathrm{ACh}$ is not yet understood, the cholinergic system is important as a mediator of behavior. A series of investigations by Glow and his co-workers (Glow, Richardson, \& Rose, 1967; Glow \& Rose, 1966; Richardson \& Glow, 1967) support this conclusion.

Acetylcholine (ACh) and cholinesterase (AChE) levels have been manipulated by selective breeding and by environmental manipulation (Rosenzweig et al, 1960), and it has been demonstrated that the ACh system meets two requirements which any chemical substrate for learning must satisfy, whether it be acting at the molar or the molecular level. First, the substrate must be capable of changing in response to sensory input. It has been shown that $\mathrm{ACh}$ and $\mathrm{AChE}$ levels at various points in the visual system can be modified by varying visual input (e.g., Liberman, 1962), and that varying the amount of experience with a specific sensory modality causes marked variations in cholinergic enzyme levels in the sensory cortex serving that modality (cf. Rosenzweig, 1966). Second, substrate level or activity must vary concomitantly with changes in behavior. A series of studies have demonstrated significant alterations both in enzyme activity and in modifications of brain structure, in rats exposed to varying behavioral experiences such as enriched or isolated environments (cf. Bennett, Diamond, Krech, \& Rosenzweig, 1964; Rosenzweig, 1966; for summaries).

One way to test a hypothesis that learning efficiency is positively correlated with the efficiency of cholinergic synaptic transmission is to increase the amount of $\mathrm{ACh}$ available at the synapse by inhibiting the action of AChE. If there is a direct positive relationship between $\mathrm{ACh}$ activity and learning, increasing the amount of $\mathrm{ACh}$ functionally available should result in improved learning ability. The purpose of this study was to investigate the effects of manipulating the $\mathrm{ACh}-\mathrm{AChE}$ system on a complex learning task. The enzyme system was manipulated via injection of a cholinesterase inhibitor (eserine) which is known to act centrally, and the task chosen was the three-table test for place learning (Hamilton \& Harned, 1944).

\section{SUBJECTS}

The Ss were 36 young adult white mice, 18 males and 18 females, of the Smith-Webster strain, obtained from the Bacteriology Department of Brigham Young University. The Ss were housed in group cages, three to a cage, and were maintained on a 24-h food deprivation schedule with free access to water.

\section{APPARATUS}

The Ss were trained and tested on a Y-shaped elevated runway with distinct goal-tables at the end of each runway. The arms of the $Y$ were $34 \mathrm{in.}$ long, $1 \mathrm{in}$. wide, and $24 \mathrm{in}$. above the floor. One table was square in shape, with a wood surface. The second table was circular in shape, with a corrugated cardboard surface, and the third table was triangular in shape, with a smooth plastic surface. All three tables were 6 in. across, and contained an opaque food dish. The apparatus and the animal's cages were located in the same room, and the apparatus was not moved during the course of the experiment. Thus, the features of the room, which were quite distinctive, provided directional cues.

\section{PROCEDURE}

The Ss were randomly divided into six groups, each of which received either an i.p. distilled water injection or one of five different dosages of i.p. eserine injection. The eserine dosages were $.05, .075, .10, .125$, or $.15 \mu \mathrm{g}$ per gram of body weight. One $S$ from the .075 group, one from the .10 group, one from the .125 group, and two from the .15 group died during the experiment, reducing the total $\mathrm{N}$ to 30 .

Pretraining consisted of six days of 5-min exploration trials on the apparatus, with all food containers in place but empty, and with Ss food-deprived but not injected. Following this experience, 15 daily test sessions were administered. For each session, each $S$ was given its respective injection, returned to the home cage for $20 \mathrm{~min}$ and then placed at the center junction of the Y-shaped runway and allowed $5 \mathrm{~min}$ of free exploration, with all food cups empty. Inaccessible food was placed under each table to offset olfactory cues. At the end of the 5-min exploration period $\mathrm{S}$ was removed from the runway while food was placed on one of the tables, replaced on the table with the food, allowed to eat for a few seconds, and then removed to one of the other tables and allowed to return to the food table. If $S$ had not reached the food table at the end of $7 \mathrm{~min}$ it was placed there and allowed to feed for a few seconds. Habitual responses were made ineffectual by completely randomizing the order of both the feeding and the starting tables from trial to trial.

Responses were recorded as a percentage score based on correct or incorrect choice at the choice point. If $S$ went directly from the starting table to the food table the trial was counted as correct. If $S$ made a wrong turn at the choice point the trial was counted as incorrect even if $S$ eventually reached the food table. A turn was credited if S's hind legs left the centerpiece of the Y-junction. Responses due to chance were eliminated by subtracting the incorrect responses from the correct responses, and this number was then divided by the total number of trials to give the percentage score. A time score, consisting of the number of seconds required to reach the food table, totalled across the 15 trials, was also recorded. RESULTS

One-way analyses of variance were performed on the percentage scores and time scores. The groups differed significantly with respect to the percentage scores $(F=2.49$, 
Table 1

Duncan's Multiple Range Test: Mean Percentage Scores

\begin{tabular}{lllllll}
\hline Group & $.15 \mu \mathrm{g}$ & $.05 \mu \mathrm{g}$ & $.125 \mu \mathrm{g}$ & $.075 \mu \mathrm{g}$ saline & $.10 \mu \mathrm{g}$ \\
Mean Percent- & -33.25 & -28.83 & -0.25 & 5.40 & 29.00 & 36.20 \\
age Score* & & & & & &
\end{tabular}

* Scores which are underlined by a common line do not differ significantly $(p=.05)$

df $=5 / 24, p<.06)$, but not with respect to the time scores $(F=1.62, d f=5 / 24, p>.10)$. A test for lieterogeneity of variance indicated that the data were homogeneous. The percentage scores were tested with Duncan's New Multiple Range Test, and the results are shown in Table 1. The . 10- $\mu \mathrm{g}$ group and the saline-injected controls did not differ, and both scored significantly higher than the $.05-\mu \mathrm{g}$ and $.15-\mu \mathrm{g}$ groups, which also did not differ from each other. The $.075-\mu \mathrm{g}$ and $.125 \mu \mathrm{g}$ groups scored neither significantly lower than the control and $.10 \mu \mathrm{g}$ groups nor significantly higher than the $.05-\mu \mathrm{g}$ and $.15-\mu \mathrm{g}$ groups.

\section{DISCUSSION}

Pretrial injection of eserine did not facilitate the learning of the task involved and, indeed, with the lowest and the highest dosages of the drug significantly impaired learning. Observation of the animals during testing indicated that the eserine-injected Ss appeared to be suffering from a motivational deficit in that they showed more fear and appeared to be more hesitant in exploring the apparatus during the initial 5-min period. However, the lack of significant differences among the time scores would appear to rule out performance deficits based on motivational differences as an explanation of the results. Also, it would be difficult to imagine why only the lowest and the highest dosages should have such an effect. While the explanation of the peculiar dosage effects awaits further research with a wider range of dosages, these results do not provide support for the hypothesis that learning efficiency, at least on the task used here, is positively correlated with increased ACh activity in the rat brain.

\section{REFERENCES}

BIENNETT, E. L., DIAMOND, M. (., KRECH, D., \& ROSENZWEIG, M. R. Chemical and anatomical plasticity of brain. Science, 1964, 146, $610-619$.

CARLTON, P. L. Cholinergic mechanisms in the control of behavior by the brain. Psychological Review, 1963, 70, 19-39.

DEUTSCII, J. A., \& DEUTSCH, D. Physiological psychology. Homewood, Ill.: Dorsey, 1966.

GLOW, P. H., RICIIARDSON, A., \& ROSE, S. Effect of reduced cholinesterase activity on the maintenance of an operant response. Journal of Comparative \& Physiological Psychology, 1967, 63, 155-157.

GLOW, P. H., \& ROSE, S. Cholinesterase levels and operant extinction. Joumal of Comparative \& Physiological Psychology, 1966, 61, 165-172.

HAMILTON, H. C., \& HARNED, B. K. The effect of the administration of sodium bromide to pregnant rats on the learning ability of the offspring. III. Three-table-test. Journal of Psychology, 1944, 18, 183-195.

LIBERMAN, R. Retinal cholinesterase and glycolysis in rats raised in darkness. Science, 1962, 135, 372-373.

REEVES, C. Cholinergic synaptic transmission and its relationship to behavior. Psychological Bulletin, 1966, 65, 321-335.

RICHARDSON, A. J., \& GLOW, P. H. Discrimination behavior in rats with reduced cholinesterase activity. Joumal of Comparative \& Physiological Psychology, 1967, 63, 240-246.

ROSENZWEIG, M. R. Environmental complexity, cerebral change, and behavior. American Psychologist, 1966, 21, 321-332.

ROSENZWEIG, M. R., KRECH, D., \& BENNETT, E. L. A search for relations between brain chemistry and behavior. Psychological Bulletin, 1960, 57, 476-492.

(Continued from page 109)

function of increasing age. The improvement was more pronounced in the aged rats than in the young rats, especially on the delayed avoidance task.

But basically, dilantin appears to improve avoidance performance of rats in a relatively nonspecific manner. Treatment enharces acquisition and retention of both discriminated and delayed avoidances by $S s$ at several age levels. Nevertheless, the delayed avoidance performance of aged Ss is most susceptible to treatment. The basis for these findings is unknown.

Independent determinations of the effects of delantin on pain-response thresholds and general activity did not reveal any alterations in these characteristics. And, at the dosages employed, drug toxicity, acute treatment effects, or disruptive side effects were highly improbable. Aged Ss attempting a difficult task may be characterized by a high anxiety level which impairs performance (Inglis, 1965; Welford, 1965). Thus, dilantin enhancement of avoidance performance may possibly be due to the drug reducing anxiety. Or, the drug may act more or less selectively on short-term memory processes. Aged Ss, who may be characterized by an immediate memory deficit, may be particularly handicapped on a delayed task (Doty, 1966; Inglis, 1965).

A possible mechanism of dilantin's effects on avoidance behavior is suggested by findings that the drug abolishes posttetanic potentiation (PTP). PTP is an apparent increase in synaptic excitability resulting from repetitive stimulation. Suppression of PTP may explain the clinical effectiveness of dilantin as well as recent findings that the drug reduces impulsiveness and distractibility in nonepileptic humans. A state of central hyperexcitability is hypothesized to characterize the aged brain (Welford, 1965; Inglis, 1965; Axelrod, 1963). This condition may be a preservation of electrophysiological activity following brain stimulation, which produces only "noise" in the system, and thus interferes with normal behavioral functioning. If this approach is accurate, then the improved conditioned avoidance performance of aged Ss given dilantin may reflect a more normal state of central electrical activity, possibly brought about by the suppression of abnormal PTP states. It is obvious that more research is needed before these highly speculative statements can be given much credence.

\section{REFERENCES}

AXELROD, S. Cognitive tasks in several modalities. In R. H. Williams, C. Tibbits, and W. Donahue (Eds.), Processes of aging, Vol, 1. New York: Atherton Press, 1963. Pp. 132-143.

DOTY, B. A. Age and avoidance conditioning. Journal of Gerontology, 1966, 21, 287-290.

GORDON, P. Diphenylhydantoin and procainamide: Normalization of sub-optimal learning behavior. In J. Wortis (Ed.), Recent advances in biological psychiatry, Vol. 10. New York: Plenum Press. Pp. 121-133.

INGLIS, J. Immediate memory, age and brain function. In A. T. Welford and J. E. Birren (Eds.), Behavior, aging and the nervous system, Springfield: Chas. Thomas, 1965. Pp. 88-113.

TOMAN, J. E. P. Drugs effective in convulsive disorders. In L. S. Goodman and A. Gilman, The pharmacological basis of the rapeutics, (3rd ed.) New York: Macmillan Co., 1965. Chap. 13.

TOMAN, J. E. P. Neuropharmacology of diphenylhydantoin. Paper presented at the Annual Meeting of American College of Neuropsychopharmacology, 1966.

WELFORD, A. T. Performance, biological mechanisms and age: A theoretical sketch. In A. T. Welford and J. E. Birren (Eds.), Behavior aging, and the nervous system. Springfield: Chas. Thomas, 1965. Pp. $3-20$.

1. Supported by NSF-URP Grant GY-2593. 